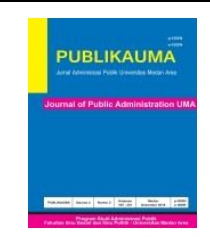

\title{
Melestarikan Tudang Sipulung Melalui Metode Brainstorming Dalam Meningkatkan Kualitas Pelayanan Pada Kantor Desa Mattirowalie
}

\section{Preserving Tudang Sipulung through Brainstorming Method to Improve Service Quality At the MattirowalieVillage Office}

\author{
Erna \& Muhammad Aris \\ Program studi Administrasi Negara, Universitas Puangrimaggalatung
}

Disetujui: Januari 2021; Direview: April 2021;Diterima: Mei 2021

\begin{abstract}
Abstrak
Tujuan penelitian ini untuk menganalisis dan menemukan ide-ide kreatif melalui brainstorming dalam tudang sipulung yang dapat digunakan untuk meningkatkan kualitas pelayanan serta hambatan pelaksanaannya di kantor Desa Mattirowalie. Jenis penelitian ini adalah kualitatif dengan teknik pengumpulan data melalui observasi, wawancara, dan analisis dokumentasi. Informan dalam penelitian ini yaitu masyarakat dan aparatur Desa Mattirowalie dengan jumlah 21 orang. Adapun Hasil dari penelitian ini yaitu penerapan brainstorming dalam tudang sipulung di Desa Mattirowalie pelaksanaanya berlangsung dengan aman dan dapat menyelesaikan masalah terkait kualitas pelayanan di Desa Mattirowalie. Hasil identifikasi masalah dalam kualitas pelayanan di Desa Mattirowalie pada pra siklus terdapat 8 (delapan) indikator yang bermasalah. Setelah dilakukan tudang sipulung dengan metode brainstorming terjadi peningkatan kualitas pelayanan, hal ini terlihat dari jumlah indikator yang bermasalah dalam kualitas pelayanan tersisa 2 (dua) indikator saja, yakni ketidakdisiplinan aparat desa dalam melakukan proses layanan dan masih ada petugas yang bersikap diskriminatif dalam memberikan pelayanan. Adapun hambatannya adalah kurangnya kesadaran masyarakat Desa Mattirowalie untuk mengikuti musyawarah desa serta masih ada ego dari peserta brainstorming untuk berdebat mempertahankan argumen.
\end{abstract}

Kata Kunci: Tudang Sipulung, Brainstorming, Kualitas Pelayan Publik

\begin{abstract}
The purpose of this research is to analyze and find creative ideas through brainstorming in the warehouse of sipulung which can be used to improve service quality and obstacles to its implementation in Mattirowalie Village office. This type of research is qualitative with data collection techniques through observation, interviews, and documentation analysis. The informants in this study were the community and the Mattirowalie Village apparatus with a total of 21 people. The results of this study are the application of brainstorming in the warehouse of slugs in Mattirowalie Village, the implementation is safe and can solve problems related to service quality in Mattirowalie Village. The results of the identification of problems in service quality in Mattirowalie Village in the pre-cycle, there were 8 (eight) problematic indicators. After carrying out the tudang sipulung with the brainstorming method, there was an increase in service quality, this can be seen from the number of problematic indicators in the service quality, the remaining 2 (two) indicators, namely the indiscipline of village officials in carrying out the service process and there are still officers who are discriminatory in providing services. The obstacles are the lack of awareness of the people of Mattirowalie Village to attend village meetings and there is still the ego of the brainstorming participants to argue to defend the argument.
\end{abstract}

Keywords: Tudang Sipulung, Brainstorming, Quality of Public Servants

How to Cite: Erna \& Aris, M. (2021). Melestarikan Tudang Sipulung melalui Metode Brainstorming dalam Meningkatkan Kualitas Pelayanan Pada Kantor Desa Mattirowalie. PUBLIKAUMA: Jurnal Ilmu Administrasi Publik UMA, Vol 9, (1): 26-37

*Corresponding author: ISSN 2549-9165 (Print)

E-mail: ernamuhammade@gmail.com

ISSN 2580-2011 (Online) 



\section{PENDAHULUAN}

Salah satu bentuk kearifan lokal yang patut dilestarikan di Kabupaten Wajo yaitu tudang sipulung merupakan acara duduk bersama dan sebagai wadah berbagi informasi dalam masyarakat dan sekaligus sebagai penyambung lidah antara masyarakat dengan pemerintah. Tudang sipulung biasanya dilaksankan oleh masyarakat tani dengan pihak pemerintah dalam membahas perkembangan pertanian di Kabupaten Wajo. Selain itu, tudang sipulung juga dilaksanakan sebagai model musyawarah antara masyarakat dan pemerintah Kabupaten Wajo dalam membahas dan mengevaluasi kualitas pelayanan pemerintah di Kabupaten Wajo.

Dalam bahasa bugis tudang berarti duduk, dan sipulung berarti berkumpul. Sehingga secara etimilogi tudang sipulung berarti duduk berkumpul atau musyawarah. Secara harfiah hal ini berarti berkumpul dengan maksud memusyawarahkan hal-hal yang dianggap penting oleh masyarakat setempat (Syahruna \& Amin, 2014). Tudang sipulung merupakan media komunikasi antara masyarakat dan pemerintah di Kabupaten Bone (Yunda et al., 2014). Selain itu, kearifan lokal juga sebagai perekat identitas bangsa, sekaligus menjadi konsep pertemuan masyarakat terdahulu, khususnya dalam bidang pertanian serta juga dapat dimanfaatkan dalam bidang pendidikan karakter. (Syahruna 2014; Fajarini, 2014; Brata, 2016; Priyatna, 2017) .

Brainstorming adalah metode memunculkan penyelesaian masalah kreatif dengan mendorong anggota kelompok untuk melemparkan ide sembari menahan kritik atau penilaian. Dalam pelaksanaan brainstorming ada beberapa tahapan yang perlu dilakukan (Syafi 'udin et al., 2018), yaitu:

(1) Kemampuan mengidentifikasi masalah; (2) Kemampuan menganalisis situasi; (3) Kemampuan mengalirkan ide-ide baru; (4) Kemampuan menganalisis ide-ide; dan (5) Kemampuan menentukan alternatif pemecahan masalah.

Adapun keuntungan yang menonjol dari teknik sumbang saran (brainstorming) adalah kebebasan untuk menyampaikan ide karena tidak ada kekhawatiran untuk dikritik atau dihentikan sebelum selesai berbicara (J. Salusu, 2015).

Tuntutan masyarakat terhadap kualitas pelayanan semakin besar sehingga dibutuhkan inovasi dalam setiap layanan. Menurut Zeithaml dkk (Hardiyansyah, 2018), kualitas pelayanan dapat diukur dari 5 (lima) dimensi, yaitu: (1) Tangible (berwujud), merupakan penampilan fasilitas fisik, peralatan, personal, dan media komunikasi dalam pelayanan; (2) Reliability (kehandalan), merupakan kemampuan pemberi layanan dalam memberikan pelayanan yang dijanjikan dengan segera memberi kepuasan serta penyelesaian dengan tepat waktu dan konsisten; (3) Responsiviness (ketanggapan), merupakan sikap tanggap yang dimiliki oleh petugas layanan dalam memberikan pelayanan kepada msyarakat; (4) Assurance (jaminan), merupakan salah satu upaya upaya perlindungan yang disiapkan dan diberikan untuk masyarakat yang mencakup pengetahuan, kemampuan, kesopanan, dan sifat dapat dipercaya, bebas dari bahaya, resiko, dan keragu-raguan; dan (5) Empathy (empati), merupakan kemudahan dalam melakukan hubungan pelayanan, menjalin komunikasi yang baik dan dan menjamin kebutuhan pengguna layanan.

Dari hasil temuan awal di lapangan, bahwa banyaknya keluhan masyarakat terkait kualitas pelayanan yang diberikan oleh aparatur Desa Mattirowalie sehingga masyarakat bersikap apatis terhadap pemerintah, kurangnya partisipasi masyarakat baik dalam perencanaan maupun pelaksanaan program pemerintah desa dan keluhan-keluhan tersebut sudah disampaikan secara langsung melalui tudang sipulung yang diselenggarakan oleh pemerintah Desa Matttirowalie. Akan tetapi, pelaksanaan tudang sipulung tersebut tidak memberikan hasil yang maksimal dan terkadang berakhir ricuh sehingga tidak menyelesaikan masalah tapi justru menimbulkan masalah baru dalam masyarakat dengan munculnya konflik yang berkelanjutan. Oleh karena itu, dalam konsep tudang sipulung diperlukan suatu metode agar konsep tudang sipulung berjalan aman. Adapun metode yang akan digunakan yaitu metode brainstorming yang dikembangkan oleh Osborn. 
Perpaduan antara tudang sipulung dengan brainstorming diharapkan mampu menciptakan situasi aman dan menghasilkan keputusan yang baik sehingga dapat digunakan untuk meningkatkan kualitas pelayanan publik pada kantor Desa Mattirowalie.

Berdasarkan uraian di atas, maka akan dilakukan penelitian terkait proses tudang sipulung dengan metode brainstorming dalam meningkatkan kualitas pelayanan pada kantor Desa Mattirowalie Kabupten Wajo beserta hambatan pelaksanaannya. Penelitian ini bertujuan untuk menganalisis dan menemukan ide-ide kreatif melalui proses tudang sipulung dengan metode brainstorming yang dapat digunakan untuk meningkatkan kualitas pelayanan serta hambatan pelaksanaannya.

\section{METODE PENELITIAN}

Penelitian ini dilaksanakan di Desa Mattirowalie Kabupaten Wajo yang merupakan salah satu dari 8 (delapan) Desa/Kelurahan yang berada di Wilayah Kecamatan Maniangpajo Kabupaten Wajo. Pemilihan lokasi pada penelitian ini dengan alasan bahwa Desa Mattirowalie Kecamatan Maniangpajo merupakan desa percontohan dan merupakan pemenang bursa inovasi desa Tahun 2019 di Kabupaten Wajo.

Penelitian ini menggunakan metode peneletian kualitatif. Bongdan dan Taylor mendefinisikan Metodelogi kualitatif sebagai prosedur penelitian yang menghasilkan data deskriptif berupa kata atau kalimat tertulis atau lisan dari orang-orang dan merupakan perilaku yang dapat diamati (Moeloeng, 2015).

Teknik pengumpulan data dalam penelitian ini adalah observasi, wawancara dan analisis dokumentasi dengan alat bantu pedoman wawancara dan alat perekam. Jumlah informan sebanyak 21 orang yaitu 15 orang informan utama/informan kunci dari kalangan masyarakat dan 6 orang informan tambahan dari aparatur Desa Mattirowalie. Untuk mengetahui kualitas pelayanan pada kantor Desa Mattirowalie maka teknik penentuan Informan utama/informan kunci pada penelitian ini menggunankan teknik accidental sampling yaitu teknik penentuan sampel berdasarkan kebetulan, yaitu konsumen yang secara kebetulan/insidental bertemu dengan peneliti dapat digunakan sebagai sampel, bila dipandang orang yang kebetulan ditemui itu cocok sebagai sumber data (sugiyono, 2017). Untuk mendukung kredibilitas dari hasil penelitian ini juga melibatkan informan tambahan dari aparatur Desa Mattirowalie dengan menggunakan teknik penentuan informan purposive sampling menurut Sugiyono, (2017) teknik ini didasarkan atas pihak-pihak yang menguasai permasalahan, memiliki data, bersedia memberikan informasi dan data yang diperlukan sesuai dengan tujuan dan manfaat penelitian.

Adapun teknik analisis data pada penelitian ini terdiri dari tiga alur sesuai dengan pendapat dari Miles dan Huberman, yaitu reduksi data, penyajian data, dan penarikan kesimpulan/verifikasi (Moeloeng, 2015).

Pada tahap pengumpulan data pada penelitian ini terjadi tahapan reduksi, pada tahapan ini untuk mengetahui kualitas pelayanan publik di Desa Mattirowalie, Peneliti menggunakan 5 (lima) dimensi kualitas pelayanan publik yang dikemukakan oleh Zeithaml. Berdasarkan dari data tersebut, Peneliti mencoba menerapkan brainstorming dalam tudang sipulung di Desa Mattirowalie dengan 3 (tiga) tahap yaitu: (1) tahap pra siklus, melakukan identifikasi masalah kualitas pelayanan dan mengumpulkan ideide kreatif dari informan; (2) tahap siklus 1 (satu), melakukan tudang sipulung dengan metode brainstorming terhadap semua ide-ide yang terkumpul dan uji coba penerapan hasilnya; dan (3) tahap siklus 2 (dua), melakukan tudang sipulung dengan metode brainstorming untuk membahas hasil uji tahap siklus 1.

Selanjutnya hasil data yang terkumpul diolah, dicatat, diklasifikasikan dan digambarkan secara objektif. Setelah tahap reduksi data maka tahapan berikutnya adalah display data atau penyajian data. Ini merupakan tahapan secara sistematis. Pada tahap ini semua data mulai dari tahap pra siklus, tahap Siklus I dan tahap siklus II disusun secara sistematis dan dikelompokan kemudian tahap berikutnya Melakukan penyajian data yang isinya berupa sekumpulan informasi yang tersusun agar peneliti lebih mudah memahami apa yang sedang terjadi dan apa yang harus dilakukan. 
Selanjutnya hasil display data atau penyajian data dari semua data yang tersusun secara sistematis di verifikasi agar lebih mudah untuk menarik kesimpulan. Penarikan kesimpulan pada penelitian ini dilakukan setelah uji coba penerapan tudang sipulung dengan metode brainstorming pada kantor Desa Mattirowalie untuk mengetahui hasil implementasi tudang sipulung dengan metode brainstorming dalam meningkatkan kualitas pelayanan publik di kantor Desa Mattirowalie.

\section{HASIL DAN PEMBAHASAN}

Secara harfiah kata tudang sipulung berarti duduk bersama. Tudang sipulung merupakan ruang bagi masyarakat untuk menyuarakan kepentingan-kepentingannya dalam rangka mencari solusi atas permasalahan yang mereka hadapi. Pada tahap penelitian ini, peneliti mencoba menerapkan metode brainstorming dalam tudang sipulung yang akan dilaksanakan di Kantor Desa Mattirowalie dengan 3 (tiga) tahap yaitu:

1. Tahap Pra Siklus

2. Tahap Siklus 1 (Satu)

3. Tahap Siklus 2 (Dua)

\section{Proses Tudang sipulung dengan Metode Brainstorming Tahap Pra Siklus}

Pada tahap pra siklus ini peneliti mengamati model diskusi dalam menyelesaikan masalah di kantor Desa Mattirowalie, yaitu masih mempertahankan budaya kearifan lokal yaitu tudang sipulung dan belum menggunakan metode brainstorming (curah pendapat). Selanjutnya, pada tahap ini langkah awal yang dilakukan oleh peneliti adalah mengidentifikasi masalah terkait kualitas pelayanan pada kantor Desa Mattirowalie.

Untuk mengetahui kualitas pelayanan publik di kantor Desa Mattirowalie, peneliti menggunakan 5 (lima) dimensi kualitas pelayanan publik yang dikemukakan oleh Zeithaml dkk (Hardiyansyah, 2018). Adapun hasil identifikasi masalah dalam kualitas pelayanan di kantor Desa Mattirowalie, yaitu:

1. Dimensi tangible (berwujud), yaitu:

a. Penampilan aparat desa dalam melayani pengguna layanan tidak rapih dan pakaiannya tidak seragam; Hal ini sesuai dengan hasil wawancara dengan informan sebagai berikut:

" Menurut M-1 Asd, M-2 Rsm, dan M-3 Wjg, M-4 Elz, bahwa penampilan aparat Desa Mattirowalie sudah lumayan rapih tapi masih perlu dibenahi, senada dengan pernyataan tersebut $M-4$ Ags, M-5 AA, $M$ 6 Nsn, dan M-7 Nsr menyatakan bahwa terkadang aparat Desa Mattirowalie memakai pakaian yang berbeda-beda ada yang memakai pakaian olahraga, ada yang seperti PNS, dan ada yang menggunakan pakaian biasa saja."

b. Kedisiplinan aparat Desa Mattirowalie masih perlu ditingkatkan karena aparat desa sering tidak berada di tempat saat jam kantor, selalu terlambat dan berkas yang diurus juga tidak tepat waktu. Hal ini sesuai dengan pernyataan informan:

"Menurut M-8 Jml, M-4 Ags, dan M-7 Nsr. Aparat desa sering tidak tepat waktu berada di kantor desa. Senada dengan hal tersebut M-2 Rsm, M-9 . I T dan M-3 Wjg menyatakan bahwa biasanya sudah banyak yang antri dikantor desa jam 10 (sepuluh) tapi aparat desa masih kurang bahkan sering ditemui kantor dalam keadaan kosong".

2. Dimensi reliability (kehandalan), yaitu:

a. Kurangnya kecermatan dari aparat Desa Mattirowalie karena masih sering terjadi salah pengetikan dan penulisan dalm bekerja. Hal ini dapat terlihat melalui hasil wawancara dengan informan sebagai berikut:

"Menurut M-10 Ismail, M-11 Amr, MNrh menyatakan bahwa dalam pengurusan surat keterangan di Desa Mattirowalie biasanya dilakukan berulang-ulang karena sering terjadi kesalahan dalam pengetikan. Hal tersebut juga diuraikan oleh M-9 I T, M7 Nsr , 'M-15 Elz dan M-12 Ibr bahwa saya pernah mengurus permohonan pembuatan Kartu Keluarga tapi terdapat beberapa kali kesalahan".

b. Kejelasan standar pelayanan di Desa Mattirowalie belum jelas. 
" Menurut Kepala Desa Mattirowalie yaitu A-1 Zrh, terkait kejelasan standar pelayanan, pemerintah Desa Mattirowalie berpedoman pada Permendagri Nomor 2 Tahun 2017 tentang Standar Pelayanan Minimal Desa atau biasa disebut SPM Desa. Akan tetapi, berbeda dengan pernyataan informan penelitian yang berasal dari masyarakat bahwa memang benar selalu dinyatakan bahwa standar pelayanananya berpedoman pada Permendagri Nomor 2 Tahun 2017 tapi yang terjadi standar operasional misalnya ketepatan waktu tidak terpenuhi, sedangkan kami masyarakat tidak mengetahui maksud Permendagri tersebut."

3. Dimensi responsiviness (ketanggapan), yaitu:

a. Pelayanan di Desa Mattirowalie tidak cepat dan memakan waktu lama; dan

b. Tidak ada ketepatan waktu dalam melayani bahkan sering terlambat. Adapun hasil wawancara dengan informan sebagai berikut:

"Terkait pelayanan dengan cepat dan tepat waktu, menurut Informan M-11 Amr, M-10 Isml, M-12 Ibr dan M-14 Asr enyatakan bahwa pelayanan di Desa Mattirowalie terkadang lambat dan tidak tepat waktu. Senada dengan itu, M-13 M A, M-7 Nsr dan, M-5 AA menyatakan bahwa kalau untuk staf desa kadang dijanji bahwa surat keterangnnya besok baru selesai tapi nyatanya saat datang besoknya saya kami disuruh menunggu”.

4. Dimensi assurance (jaminan), yaitu tidak ada jaminan tepat waktu dalam melayani masyarakat.

Berdasarkan hasil wawancara dengan informan terkait dimensi responsiviness (ketanggapan), yaitu:

a. Pelayanan di Desa Mattirowalie tidak cepat dan memakan waktu lama;

b. Tidak ada ketepatan waktu dalam melayani bahkan sering terlambat. Maka dapat disimpulkan bahwa tidak ada jaminan tepat waktu dalam melayani masyarakat di Desa Mattirowalie.

5. Dimensi empathy (empati), yaitu masih ada perlakuan diskriminatif dalam melayani masyarakat . Hal ini dapat terlihat dari hasil wawancara dengan informan sebagai berikut:

"Menurut M-6 Nrs, M-9 It, dan M-12 Ibr, bahwa Aparat Desa Mattirowalie melayani dengan sangat baik kecuali terkait pelayanan bantuan sosial, mayoritas keluarga dari aparat desa yang mendapatkan. Hal tersebut juga sesuai dengan pernyataan dari $M-14$ Asr, M-13 $M$ A, M-7 Nsr, M-11 Amr, dan M-Asr bahwa rata-rata yang mendapatkan bantuan sosial adalah rumpun keluarga".

\section{Tahap Siklus I}

Pada tahap siklus I, Peneliti merancang dan menyiapkan proses tudang sipulung dengan metode brainstorming. Pada tahap ini, Adapun tahapan yang perlu dilakukan dalam tahap siklus I, yaitu:

1. Membentuk kelompok brainstorming, Pada tahap ini tim peneliti bertindak sebagai mediator atau fasilitator dalam brainstorming dan membentuk kelompok brainstorming. Pelaksanaan brainstorming pada siklus 1 (satu) dilakukan sebanyak $2 \mathrm{X}$ 45 menit setiap pertemuan.

2. Memilih prosedur saat melakukan kegiatan tudang sipulung dengan metode brainstorming. Pada tahap ini brainstorming akan dilaksankan secara langsung untuk mencari penyelesaian masalah dari hasil identifikasi masalah dalam kualitas pelayanan pada Kantor Desa Mattirowalie, dimana pada tahap ini prosedur yang dapat dipilih yaitu semua anggota kelompok diperbolehkan untuk menuliskan, membagikan, dan mengomentari sebuah gagasan anggota lainnya tanpa diminta untuk berdiri atau berbicara;

3. Membuat kesepakatan awal, bahwa brainstorming ini dikendalikan oleh peneliti sebagai mediator, segala aturan berdiskusi untuk menyampaikan ide harus seizin dari mediator brainstroming;

4. Mengumpulkan ide kreatif sebanyakbanyaknya dari peserta brainstorming(Pertemuan I) 
5. Menentukan ide kreatif, Melakukan verifikasi terhadap semua ide-ide kreatif yang terkumpul (Pertemuan II); dan

6. Melakukan pengamatan langsung terhadap penerapan hasil brainstorming dalam menyelesaikan masalah pelayanan di Desa Mattirowalie.

Pada pertemuan I, hasil tudang sipulung dengan metode brainstorming (terhadap ideide kreatif yang terkumpul), yaitu:

1. Dimensi tangible (berwujud)

Terkait penampilan aparat desa dalam melayani, yaitu: (a) Bagi yang tidak berpakaian rapih sebaiknya dikenakan sanksi; (b) Kepala desa memberikan contoh pakaian yang rapih kepada bawahannya; (c) Sebaiknya Kepala Desa melakukan sidak; dan (d) Perlu ada SOP terkait aturan berpakaian bagi aparat.

Adapun terkait kedisiplinan aparat desa melakukan proses layanan, yaitu: (a) Sanksi bagi aparat yang sering tidak masuk harus dipertegas; (b) Buat tim pengawasan dari masyarakat; (c) Berikan penghargaan bagi aparat desa yang rajin; dan (d) Lakukan rapat untuk membahas kedisiplinan pegawai.

2. Dimensi reliability (kehandalan)

Terkait kecermatan dalam memberikan pelayanan, yaitu: (a) Ketikan diperiksa terlebih dahulu oleh aparat yang lain sebelum dicetak; (b) Buat SOP pemeriksaan sebelum surat keterangan yang dibuat diserahkan kepada masayarakat; (c) Perlihatkan kepada masyarakat hasil ketikan sebelum diprint; dan (d) Jika berkali-kali salah pengetikan semestinya diberikan sanksi yang tegas agar lebih berhati-hati lagi.

Adapun terkait kejelasan standar pelayanan, yaitu: (a) Buat SOP pelayanan dan tempel di kantor desa; (b) Adakan tudang sipulung untuk membahas kejelasan standar pelayanan di Desa Mattirowalie; (c) Kejelasan standar pelayanan harus dipaparkan pada setiap musyawarah desa; (d) Buat alur standar pelayanan dan informasikan melalui pertemuan dengan masyarakat.

3. Dimensi responsiviness (ketanggapan)

Terkait kecepatan dan ketepatan dalam melayani, yaitu: (a) Kepala Desa wajib memberikan sanksi bagi aparat yang memberikan pelayanan tidak cepat dan tepat; (b) Lakukan breaving untuk memonitor pelayanan; (c) Sebaiknya diadakan apel pagi dan sidak seperti pada kantor kecamatan dan kelurahan; (d) Kepala Desa menjadwalkan pertemuan untuk mengevaluasi aparatnya; dan .

4. Dimensi assurance (jaminan)

Terkait jaminan terhadap ketepatan waktu dalam pelayanan, yaitu:

a. Berikan denda kepada aparat yang membiarkan masyarakat menunggu lebih dari satu hari;

b. Aparat harus menjamin tepat waktu pelayanan dan meminta nomor telepon masyarakat yang dilayani untuk diberikan informasi terkait pelayanan yang dilakukan;

c. Berikan jaminan bahwa jika keperluan masyarakat tidak selesai tepat waktu maka aparat harus mengantarkan keperluan tersebut ke rumah masyarakat;dan

d. Berikan jaminan bahwa jika keperluan masyarakat tidak selesai tepat waktu maka aparat harus mengantarkan keperluan tersebut ke rumah masyarakat.

5. Dimensi emphaty (empati)

Terkait petugas melayani dengan tidak diskriminatif, yaitu:

a. Lakukan sosialisasi jika ada bantuan dari pemerintah;

b. Lakukan pendataan yang maksimal terkait masyarakat yang berhak dapat bantuan;

c. Libatkan masyrakat untuk membahas bantuan pemerintah;

d. Berikan pemahaman kepada masyarakat tentang siapa saja yang berhak atas bantuan tersebut; dan

e. Lakukan pendataan secara spesifik agar bantuan tepat sasaran.

Setelah kelompok brainstorming memilih beberapa ide kreatif pada pertemuan pertama, maka dilanjutkan kembali pertemuan kedua tudang sipulung dengan metode brainstorming untuk memilih ide-ide kreatif yang dapat menyelesaikan masalah dalam kualitas pelayanan. 
Pada pertemuan II, hasil tudang sipulung
dengan metode brainstorming untuk
menentukan ide kreatif yang dapat menyelesaikan masalah dalam kualitas pelayanan di Desa Mattirowalie, yaitu:

1. Dimensi tangible (berwujud) dengan solusi agar Kepala Desa wajib melakukan sidak, dan bagi aparat yang ditemukan tidak berpakaian rapih dan tidak disiplin sesuai SOP maka akan diberikan sangksi ringan berupa teguran dan sangksi yang tegas yaitu pemberhentian jika tetap melakukan pelanggaran;

2. Dimensi reliability (kehandalan) dengan solusi agar dibuat SOP pemeriksaan sebelum surat keterangan yang dibuat diserahkan kepada masayarakat dan kejelasan standar pelayanan harus di paparkan pada setiap musyawarah desa;

3. Dimensi responsiviness (ketanggapan) dengan solusi agar Kepala Desa menjadwalkan pertemuan untuk mengevaluasi aparatnya dan memberikan sanksi yang tegas jika masih ada kelalaian dalam kecepatan dan ketepatan dalam melayani;

4. Dimensi assurance (jaminan), dengan solusi agar memberikan jaminan bahwa jika keperluan masyarakat tidak selesai tepat waktu maka aparat harus mengantarkan keperluan tersebut ke rumah masyarakat; dan

5. Dimensi empathy (empati), dengan solusi agar melakukan sosialisasi jika ada bantuan dari pemerintah dan berikan pemahaman kepada masyarakat terkait prosedur yang perlu dipenuhi agar dapat mendapatkan bantuan melalui musyawarah desa.

\section{Observasi Hasil Siklus 1}

Pada tahap ini Tim Peneliti bersama dengan informan dari masyarakat yang dipilih secara acak melakukan pengamatan terhadap penerapan hasil brainstorming dalam menyelesaikan masalah pelayanan di Desa Mattirowalie. Pengamatan dilakukan dalam waktu 2 (dua) bulan, yaitu pada bulan JuliAgustus 2020.

1. Dimensi tangible (berwujud)

a. Terkait penampilan aparat desa dalam melayani,

"Menurut Informan (masyarakat) bahwa setelah adanya implementasi hasil brainstorming, aparat Desa Mattirowalie sudah berpakaian rapih sesuai dengan SOP. Akan tetapi, demi kelancaran pelayanan aparat Desa Mattirowalie tidak hanya melayani di Kantor Desa saja tapi di luar jam kantor, sehingga terkadang tidak tampil rapih di depan masyarakat".

b. Terkait masalah kedisiplinan aparat Desa Mattirowalie.

"Menurut Informan (masyarakat) pada penelitian ini bahwa setelah diterapkan hasil brainstorming masih ditemukan aparat desa yang terlambat atau tidak ditempat saat jam kantor. Sedangkan Menurut Kepala Desa Mattirowalie yaitu A-1 Zrh menyatakan bahwa, untuk masalah kedisiplinan sangat sulit diukur dalam masa pandemi karena memang aparat lebih banyak melayani dirumah dan biasa datang pada siang hari".

2. Dimensi realiability (kehandalan)

a. Terkait kecermatan dalam memberikan pelayanan,

"Menurut Informan dalam penelitian ini, bahwa dengan adanya SOP pemeriksaan sebelum surat keterangan yang dibuat dan diserahkan kepada masyarakat dapat meminimalisir kesalahan penulisan dan pengetikan yang dilakukan oleh aparat Desa Mattirowalie. Hal ini dibuktikan dengan tidak ada keluhankeluhan masyarakat terkait kesalahan dalam pengetikan ataupun penulisan ".

b. Terkait standar pelayanan di Desa Mattirowalie

" Menurut Kepala Desa Mattirowalie bahwa sesuai dengan hasil tudang sipulung maka aturan terkait standar pelayanan Permendagri Nomor 2 Tahun 2017 tentang Standar Pelayanan Minimal Desa dipaparkan setiap Musyawarah Desa . Bahkan, aturan tersebut juga dipaparkan dalam Musyawarah Penyusunan RKPDs 2021 dan Musyawarah Desa Daftar Usulan RKPDs Tahun 2022 di Desa Mattirowalie".

3. Dimensi responsiviness (ketanggapan) Hasil penelitian terkait masalah pelayanan yang kadang lambat dan tidak tepat di Desa Mattirowalie, setelah diterapkan hasil brainstorming masih ditemukan keluhan masyarakat terkait lambatnya pelayananan dan kadang tidak sesuai dengan yang 
diinginkan masyarakat. Hal ini disebabkan karena pada masa pandemi aparat lebih melayani di rumah.

4. Dimensi assurance (jaminan).

Berdasarkan hasil wawancara dengan Informan (masyarakat) pada penelitian ini Terkait hasil penelitian menunjukkan bahwa aparat Desa Mattirowalie sudah memberikan jaminan tepat waktu dalam melayani masyarakat. Sesuai dengan hasil brainstorming.

5. Dimensi empathy (empati)

Adapun hasil penelitian ini bahwa, setelah dilakukan sosialisasi dalam Musyawarah Desa terkait bantuan sosial serta prosedur yang berhak mendapatkan bantuan sosial yang ada di Desa Mattirowalie bahwa;

"Menurut Informan (masyarakat) masih ada sikap membeda-bedakan dalam pembagian bantuan sosial. Menurut Kepala Desa Mattirowalie A-1 Zrh bahwa hal ini disebabkan karena masih banyak data masyarakat yang tidak diperbaharui dan terkadang ada dari masyarakat yang justru mengusir petugas survei data karena merasa tidak penting untuk disurvei".

\section{Tahap Siklus II}

Pada tahap ini, peneliti kembali melakukan tudang sipulung dengan metode brainstorming untuk membahas hasil brainstorming pada tahap siklus I. Adapun hasil identifikasi masalah dari tahap siklus I, yaitu:

1. Dimensi tangible (berwujud) dengan masalah tingkat kedisplinan masih kurang karena masih ditemui aparat desa di Desa Mattirowalie yang terlambat dan tidak ada pada saat jam kantor.

2. Dimensi empathy (empati) dengan masalah aparat Desa Mattirowalie masih melayani dengan diskriminatif terutama terkait bantuan sosial, dimana yang mendapatkan merupakan keluarga dekat.

Adapun tahapan-tahapan pada siklus II sama dengan tahapan pada siklus I, yaitu:

1. Membentuk kelompok brainstorming;

2. Memilih prosedur saat melakukan kegiatan tudang sipulung dengan metode brainstorming;

3. Membuat kesepakatan awal;

4. Membahas hasil brainstorming pada siklus I dan memilih ide kreatif yang dapat menyelesaikan permasalahan dalam kualitas pelayaan pada siklus I;

5. Melakukan pengamatan langsung terhadap penerapan hasil brainstorming dalam menyelesaikan masalah pelayanan di Desa Mattirowalie.

Dari hasil tudang sipulung dengan menggunakan metode brainstorming, peneliti yang bertindak sebagai fasilitator brainstorming beserta peserta kelompok brainstorming memutuskan untuk tetap melaksanakan ide kreatif yang terpilih pada brainstorming tahap I dengan alasan pertimbangan, sebagai berikut:

Indikator: Kedisiplinan Aparat Desa dalam melakukan proses layanan

Adapun hasil penelitian ini menunjukkan bahwa masalah kedisiplinan sangat sulit di ukur dalam masa pandemi ini karena memang aparat desa lebih banyak melayani di rumah dan biasa datang pada siang hari.

Dari hasil penelitian menunjukkan bahwa terkait masalah kedisiplinan aparat Desa Mattirowalie bahwa;

"Menurut M-15 Elz, M-12 Ibr, M-14 Asr bahwa saya masih menemukan aparat desa datang jam 11 di kantor desa. Senada dengan hal tersebut M-10 Ism, M-8 Jml, dan M-14 Asr mengatakan bahwa sepertinya tidak ada perubahan karena masih sering dijumpai aparat yang tidak disiplin. Begitupun dengan M-9 It menyatakan bahwa jangankan jam 11, jam sudah menunjukkan pukul 9 akan tetapi, masih sepi di kantor desa."

Terkait hal tersebut kepala Desa Mattirowalie A-1 Zrh menyatakan bahwa; "bukannya kami tidak disiplin, memang kalau di kantor biasanya jam 9 atau jam 10 aparat saya baru kekantor. Akan tetapi, kami siap melayani diamanpun kami berada seperti saat saya ke sawah tanpa menngunakan pakaian kantor jika memang sangat dibutuhkan saya segera membantu. Oleh karena itu, walapun saya ke sawah tetap saya bawa pulpen. Sependapat dengan hal tersebut A-2 Rzk, A-3 My, A-4 Azr, bahwa kami juga terkadang melayani masyarakat dirumah dan menurut A-5 Stw dan A-6 Ism bahwa saya terkadang bertemu dengan masyarakat diluar jam kantor saat saya berpapasan dijalan dan masyarakat tersebut membutuhkan tanda tangan dari kepala desa, 
saya langsung membantu masyarakat tersebut."

$\begin{array}{lc}\text { Indikator: } & \text { Petugas Melayani Dengan } \\ \text { Tindakan } & \text { Diskriminatif } \\ \text { Bedakan) } & \end{array}$

Hasil penelitian memperlihatkan bahwa setelah dilakukan sosialisasi dalam musyawarah desa sesuai hasil brainstorming pada siklus I terkait bantuan sosial serta prosedur yang berhak mendapatkan bantuan sosial yang ada di Desa Mattirowalie.

"Menurut informan (masyarakat) masih ada sikap membeda-bedakan dalam pembagian bantuan sosial. Menurut Kepala Desa A-1 Zrh, hal ini disebabkan karena masih banyak data masyarakat yang tidak diperbaharui dan terkadang ada dari masyarakat yang justru mengusir petugas survei data karena merasa tidak penting utuk disurvei. Sehingga Perlu ada pendataan ulang dari Pemerintah terkait".

Berdasarkan hasil temuan dalam penelitian ini, dapat disimpulkan bahwa penerapan metode brainstorming dalam tudang sipulung di kantor Desa Mattirowalie dapat menyelesaikan masalah terkait kualitas pelayanan di Desa Mattirowalie. Selain itu, Pelaksanaan tudang sipulung dapat berlangsung dengan aman setelah adanya penerapan metode brainstorming yang mengharuskan peserta untuk menyampaikan ide-ide kreatif yang sebanyak-banyakya sambil menahan diri untuk tidak memberikan kritik dan penilaian sehingga tidak terjadi perdebatan. Hal ini sejalan dengan teori dari Osborn bahwa Brainstorming adalah metode memunculkan penyelesaian masalah kreatif dengan mendorong anggota kelompok untuk melemparkan ide sembari menahan kritik atau penilaian. (Syafi udin et al., 2018).

Pada penelitian sebelumnya budaya tudang sipulung sangat dimanfaatkan dalam sektor pertanian yaitu tudang sipulung mempunyai peranan penting dalam menentukan harga margin minimun keuntungan yang diperoleh petani/pesawah. Akan tetapi budaya ini tidak diamalkan lagi akibat perubahan sosial didalam masyarakat, termasuklah perubahan nilai akibat teknologi, pembangunan zaman, paradigma berfikir masyarakat yang sudah bertukar, inovasi baru dan norma agama ( Syahruna \& Amin, 2014). Menurut Andi Artianingsih tudang sipulung merupakan media komunikasi antara masyarakat dan pemerintah di Kabupaten Bone
(Yunda et al.,2014). Sedangkan untuk brainstorming merupakan metode yang dikembangkan oleh Osborn yaitu metode memunculkan penyelesaian masalah kreatif dengan mendorong anggota kelompok untuk melemparkan ide sembari menahan kritik atau penilaian. Selain itu, Brainstorming juga dapat digunakan sebagai model penyelesaian masalah dalam pengambilan keputusan stratejik (J. Salusu, 2015). Pada penelitian terdahulu terkait dengan metode Brainstorming sangat banyak digunakan sebagai model belajar dalam meningkatkan prestasi siswa, brainstorming juga pernah diterapkan dalam diklat masyarakat budidaya dan pengolahan aren Kabupaten Pangkep (labahi, P. 2019), dan penerapan brainstorming juga diterapkan terhadap peningkatan pengetahuan tantang gaangguan akibat kekurangan iodium di Kabupaten Pati (Hapsari, 2011).

Pada penelitian ini budaya tudang sipulung akan diangkat kembali sebagai kearifan lokal yang patut dilestarikan tidak hanya di gunakan sebagai media komunikasi antara masyarakat dengan pemerintah secara vertikal dan lebih banyak diterapkan dalam bidang pertanian. Akan tetapi, digunakan sebagai media komunikasi antara masyarakat dengan pemerintah dalam meningkatkan kualiatas pelayanan pemerintah kepada masyarakat. Selain itu, budaya tudang sipulung pada penelitian ini sangat berbeda dari penelitian-penelitian sebelumnya bahwa pada penelitian ini tudang sipulung dilaksanakan dengan konsep yang berbeda yaitu dengan menerapkan metode brainstorming dalam pelaksanaan tudang sipulung. Dengan tujuan bahwa, perpaduan antara tudang sipulung dengan metode brainstorming diharapakan mampu menciptakan situasi aman dan menghasilkan keputusan yang baik sehingga dapat digunakan untuk meningkatkan kualitas pelayanan publik di Kantor Desa Mattirowalie.

Penerapan metode brainstorming dalam tudang sipulung di kantor Desa Mattirowalie menunjukkan adanya peningkatan kualitas pelayanan di Desa Mattirowalie, hal tersebut dapat terlihat dari hasil identifikasi masalah dalam kualitas pelayanan di Desa Mattirowalie pada pra siklus yaitu ada 8 (delapan) indikator yang bermasalah. Setelah dilakukan tudang sipulung dengan metode brainstorming, jumlah indikator yang bermasalah dalam peningkatan 
kualitas pelayanan berkurang menjadi 2 (dua) indikator saja yakni ketidakdisiplinan aparat desa dalam melakukan proses layanan dan petugas melayani dengan tindakan diskriminatif (membeda-bedakan).

Inovasi kearifan lokal berupa penerapan tudang sipulung dengan metode brainstorming di Desa Mattirowalie yang menunjukkan adanya peningkatan kualitas pelayanan di Desa Mattirowalie searah dengan hasil kajian Amalia, 2018 dan Yayat, 2017. Selain itu, hubungan anatara pemerintah Desa Mattirowalie dengan masyarakat terjalin dengan baik dengan adanya pelibatan masyarakat untuk duduk bersama menyampaikan semua ide kreatif yang sifatnya membangun serta pelibatan dalam rencana maupun pelaksanaan program pemerintah desa.

Adapun hambatan dalam pelaksanaan proses tudang sipulung dengan menggunakan metode brainstorming, adalah: (1) Kurangnya kesadaran masyarakat Desa Mattirowalie untuk mengikuti musyawarah desa, bahkan peneliti mengikuti kegiatan musrembang di Desa Mattirowalie sangat terlihat jika peserta musrembang dari masyarakat sangat kurang, hanya didominasi oleh aparat pemerintahan dari kantor Kecamatan Maniangpajo; (2) Masih ada ego dari peserta brainstorming untuk berdebat mempertahankan argumen sehingga terkadang menghasilkan konflik; dan (3) Penelitian ini dilaksanakan pada masa pandemi sehingga dilarang untuk berkumpul yang mengakibatkan ada beberapa indikator yang bermasalah dan belum terselesaikan misalnya kedisiplinan aparat desa.

\section{KESIMPULAN}

Penerapan metode brainstorming dalam tudang sipulung dapat menyelesaikan masalah terkait kualitas pelayanan di Desa Mattirowalie. Hal tersebut dapat terlihat pada tahap pra siklus yaitu ada 8 (delapan) indikator yang bermasalah. Setelah dilakukan tudang sipulung dengan metode brainstorming, jumlah indikator yang bermasalah berkurang menjadi 2 (dua) indikator saja.

Adapun hambatan pelaksanaanya yaitu Kurangnya kesadaran masyarakat Desa Mattirowalie untuk mengikuti musyawarah desa, Masih ada ego dari peserta brainstorming untuk berdebat mempertahankan argumen dan Penelitian ini dilaksanakan pada masa pandemi sehingga dilarang untuk berkumpul.

\section{UCAPAN TERIMAKASIH}

Tim peneliti mengucapkan terimakasih kepada Dana Riset dan Pengabdian Kepada Masyarakat (DRPM) Kemenristekdikti, Lembaga Layanan Pendidikan Tinggi (LLDIKTI) Wilayah IX, Rektor dan segenap jajaran Universitas Puangrimaggalatung, Dekan dan seluruh rekan dosen pada Fakultas Ilmu Administrasi dan terkhusus kepada Kepala Desa Mattirowalie beserta aparat Desa Mattirowalie, serta seluruh jajaran masyarakat Desa Mattirowalie.

\section{DAFTAR PUSTAKA}

Amalia, S. (2018). Reformasi Birokrasi 4.0: Strategi Menghadapi Revolusi Industri 4.0. Jurnal Wacana Kinerja: Kajian Praktis-Akademis Kinerja Dan Administrasi Pelayanan Publik, 21(2), 1-18.

Brata, I. (2016). Kearifan Budaya Lokal Perekat Identitas Bangsa. Jurnal Bakti Saraswati, 5(1), 9-16.

Cahyadi, R. (2016). Inovasi Kualitas Pelayanan Publik Pemerintah Daerah. Fiat Justiciajurnal Ilmu Hukum Fakultas Hukum Universitas Lampung, 10(3), 569-586.

Fajarini, U. (2014). Peranan Kearifan Lokal Dalam Pendidikan Karakter. SOSIO DIDAKTIKA: Social Science Education Journal, 1(2), 123130.

Firdayanti. (2019). The Role of "Tudang Sipulung" in Farming Operation in Bone District. $\mathrm{La}$ Geografia, 17(3), 209-216.

Hapsari, M.R (2011). Pengaruh Penerapan Metode Brainstorming Disertai Pemutaran Video Terhadap Peningkatan Pengetahuan Tentang Gangguan Akibat Kekurangan Iodium Pada Siswa Kelas V SDN Gunungwungkal Kecamatan Gunungwungkal Kabupaten Pati Tahun Ajaran 2010/2011 (Doctoral Dissertation, Universitas Negeri Semarang).

Hardiyansyah. (2018). Kualitas Pelayanan Publik: Konsep, Dimensi, Indikator, dan Implementasinya. Gava Media: Yogyakarta.

J Salusu, M.A. (2015). Pengambilan Keputusan Stratejik. Gramedia Widiasarana.

Kurniawan, R. C. (2017). Inovasi Kualitas Pelayanan Publik Pemerintah Daerah. Fiat Justisia, 10(3), 569-586. 
Labahi, P. A. (2019). Penerapan Metode "Brainstorming" Pada Diklat Masyarakat Budidaya dan Pengolahan Aren Kabupaten Pangkep. Jurnal Ecosystem, 19(April), 109116.

Moleong, L.J.(2017). Metodologi Penelitian Kualitatif (Revisi). Bandung: PT Remaja Rosdakarya.

Priyatna, M. (2017). Pendidikan Karakter Berbasis Kearifan Lokal. Edukasi Islami: Jurnal Pendidikan Islam, 5(10), 1311-1336.

Syafi udin, M., Wantiyah, W., \& Kushariyadi, K. (2018). Pengaruh Pendidikan Kesehatan Metode Brainstorming dan Video terhadap Pengetahuan tentang Demam Berdarah pada Keluarga di Wilayah Kerja Puskesmas Puger Kabupaten Jember. Pustaka Kesehatan, 6(1), 141.

Syahruna, A. R., \& Amin, M. (2014). Peranan Budaya Tudang Sipulung/ Appalili dan Faktor-faktor yang Memengaruhi Bergesernya Nilai Budaya Pertanian di Sulawesi Selatan. 7(November), 241-256.

Sugiyono, P. D. (2017). Metode Penelitian Bisnis: Pendekatan Kuantitatif, Kualitatif, Kombinasi, dan R\&D. Penerbit CV. Alfabeta: Bandung.

Yayat, R. (2017). Kualitas Pelayanan Publik Bidang Administrasi Kependudukan di Kecamatan Gamping. Jurnal Ilmiah Magister Ilmu Administrasi (JIMIA), 2, 56-65.

Yunda, A. A., Mirsa, S., \& Wardah, W. (2018). Revitalisasi Tudang Sipulung Sebagai Media Komunikasi Vertikal Antara Masyarakat dan Pemerintah Di Kabupaten Bone. JPP (Jurnal Politik Profektik), 6(2), 264-278. 